\title{
Comparative study of mechanical properties for substitution of normal weight coarse aggregate with oil-palm-boiler clinker and lightweight expanded clay aggregate concretes
}

\author{
Jin Chai Lee ${ }^{1}$, Payam Shafigh ${ }^{2 *}$, Syamsul Bahri ${ }^{3}$ \\ ${ }^{I}$ Department of Civil Engineering, Faculty of Engineering, UCSI University, Cheras 56000 Kuala \\ Lumpur, Malaysia \\ ${ }^{2}$ Department of Building Surveying, Faculty of Built Environment, University of Malaya, 50603 Kuala \\ Lumpur, Malaysia \\ ${ }^{3}$ Department of Civil Engineering, Politeknik Negeri Lhokseumawe, Lhokseumawe, Indonesia \\ *pshafigh@um.edu.my
}

Received: $26^{\text {th }}$ December 2019

Final version received: $30^{\text {th }}$ December 2019

This paper deals with a comparatively study of the engineering properties of the Oil-palm-boiler clinker (OPBC) OPBC and lightweight expanded clay aggregate (LECA) concretes. A grade 70 normal-weight concrete was designed as control mix. Normal weight coarse aggregate was substituted with OPBC and LECA up to $100 \%$ by volume, respectively. Their properties - workability, density, compressive strength, splitting tensile strength, flexural strength, modulus of elasticity, and water absorption - were studied. Results showed that at the same mix proportion, all mixes exhibited acceptable workability, except for concrete containing LECA up to $75 \%$ onwards, which required the reduction of superplastisizer dozen to $16 \%$. Mixes with $75 \%$ onwards LECA content exhibited acceptable workability. The oven dry density of concrete containing 100\% OPBC and 50\% LECA onwards, respectively, in this study can be considered as lightweight concrete. The use of saturated OPBC and LECA in concrete improves the mechanical properties of concrete under air drying condition. The ceiling strength of LECA concrete is at the early age of 7 days, whereas it happens to normal weight concrete and OPBC concrete at a later age. The water absorption of all mixes is below $3 \%$, which can be considered as good concrete.

Keywords: Oil-palm-boiler clinker (OPBC), lightweight expanded clay aggregate (LECA), mechanical properties, water absorption

\section{INTRODUCTION}

The building industry is currently facing a critical issue, that is, significant reduction of raw materials that are primarily used in the production of concrete (e.g., crushed rock, gravel, sand, and water) to cater to the needs of the industry (Mefteh et al. 2013). To address the extinction of resources, the utilization of recycled aggregate in concrete can be promoted (Ramezanianpour et al. 2009). Large amounts of not less than 10 billion tons of concrete are produced annually due to the rapid development of the construction industry (Meyer 2009). Thus, to cope with mass production, natural aggregates are needed to compensate for the approximately 8 to 12 billion tons depleted per year after 2010 (Tu et al. 2006). By 2050, the number of concrete needed will increase to 18 billion tons per year (Mehta and Monteiro 2006).

The primary ingredient of concrete is aggregates. Several studies have been conducted to achieve not only a lightweight but also sustainable concrete (Lee et al. 2017a; 2017b; Shafigh et al. 2018). Ground-granulated blast furnace slag, fly ash, and recycled concrete are classified as waste materials that have successfully transformed into aggregate supplant and have been utilized for decades (Federico and Chidiac 2009; Meyer 2009).

Malaysia contributes approximately $39 \%$ of world palm oil production and $44 \%$ of world export and disposes approximately $45,750 \mathrm{~m} 3$ of oil-palm-boiler clinker (OPBC) from the palm oil mill in Sabah annually. These statistics make 
Malaysia as one of the major palm oil producers globally (Mannan and Neglo 2010). Malaysia, however, has been facing the problem of disposal recently. The OPBC is a type of waste from the palm oil industry, which is generated from further combustion of palm oil fiber and oil palm shell (OPS) in the rotary kiln to produce fuel for electricity. The OPBC is generally treated as a waste with low market value because it is usually discarded arbitrarily in landfill areas or used for filling up potholes on access roads (Kanadasan and Razak 2015). Reusing the OPBC for production of concrete would therefore be economical and environment friendly.

Nevertheless, the breaking of traditional philosophy of incorporating the OPBC in the manufacture of lightweight concrete has brought several advantages in different respects. By designing the OPBC as self-compacting concrete, its 28-day compressive strength can reach up to 60 to $75 \mathrm{MPa}$ (Kanadasan and Razak 2015).

Through the substitution of coarse and fine aggregate with OPBC and adding of $10 \%$ fly ash, the $42 \mathrm{MPa}$ comparable strength of lightweight concrete can be obtained (Ahmad and Mohd 2007). The slump value of this concrete is 125 $\mathrm{mm}$, whereas its water-cement ratio is 0.55 . This slump value demonstrates that the mixture is as relatively feasible as normal weight concrete.

The inclusion of OPBC as coarse aggregate can produce a mixture with 28-day compressive strength of $45 \mathrm{MPa}$ (Ahmmad et al. 2014). This amount of strength is achieved by employing low water-cement ratio of approximately 0.331 , as well as adding superplasticizer that can improve the workability. The slump value and density of $124 \mathrm{~mm}$ and $1,948 \mathrm{~kg} / \mathrm{m} 3$ are achieved, respectively.

Lightweight expanded clay aggregate (LECA) is manufactured by burning clay at a temperature of approximately $1,150{ }^{\circ} \mathrm{C}$ in a rotary kiln. It is an artificial aggregate that can be used as an alternative material for concrete manufacturing. After heating fabrication, the volume of the material expanded to about four to five times. Sintering of raw material to produce the material is the main reason for the excessive amount of LECA. The LECA can be incorporated into concrete to improve the properties of concrete as LECA and possess good insulation characteristics (Netweber 2015; Priyadharshini et al. 2012). By substituting normal fine and coarse aggregates with LECA with low water-cement ratio, compressive strength of up to $47 \mathrm{MPa}$ is successfully achieved with the density ranging from 1,435 to $1,753 \mathrm{~kg} / \mathrm{m} 3$ (Bogas et al. 2014).

High-strength lightweight concrete with 28-day compressive strength of 45 to $50 \mathrm{MPa}$ and densities of 1790 to $1825 \mathrm{~kg} / \mathrm{m} 3$ can be produced by substitution of normal coarse aggregate with LECA (Moreno et al. 2014). Mousa et al. (2014) reported that adding LECA under saturated surface dry (SSD) condition is advantageous because it can be used as internal curing agent in the mixture. Therefore, lightweight aggregate concrete (LWAC) with 28-day compressive strength ranging from 41 to $45 \mathrm{MPa}$ is successfully obtained. The inclusion of LECA leads to an appreciation of $10 \%$ to $17.5 \%$ of compressive strength compared with those without LECA. Mousa et al. (2014) also found that the use of LECA as self-curing agent increases compressive strength and substantially boosts tensile strength, flexural strength, and modulus of elasticity (MOE) by $3.7 \%$ to $7.4 \%$, $1.6 \%$ to $7.2 \%$, and $1.4 \%$ to $4.1 \%$, respectively.

The addition of LECA with $20 \%$ silica fume as binder in the mix can produce $71 \mathrm{MPa}$ compressive strength (Novokshchenov and Whitcomb 1990) and achieve a relatively low density value of approximately $1860 \mathrm{~kg} / \mathrm{m} 3$ only. With the inclusion of LECA, silica fume, and fly ash in manufacturing lightweight concrete, 365day compressive strength of up to $70 \mathrm{MPa}$ is achieved (Malhotra 1990).

The substitution of coarse and fine aggregates with LECA produces lightweight concrete with 28-day compressive strength of $59 \mathrm{MPa}$ and slump values ranging from $50 \mathrm{~mm}$ to $245 \mathrm{~mm}$ with the addition of superplasticizer (Bogas and Gomes 2013). These data confirm the success and proper workability of the concrete mix. The concrete products are also weighed significantly lower than conventional concrete, ranging from 1607 to $1996 \mathrm{~kg} / \mathrm{m} 3$. According to all the presented data, the strength of lightweight concrete is concluded as it is primarily relies on its lightweight aggregate (Bogas and Gomes 2013).

This investigation primarily aims to explore a novel LWAC by comparing several engineering properties between the high-strength LWAC of OPBC, which is an environmentally friendly and 
low-cost local solid waste, with those of artificial LECA concrete, which is a costly material imported from Malaysia. High-strength normal weight concrete was substituted with coarse aggregate with OPBC and LECA in different percentages to evaluate various properties, such as workability, density, compressive strength with different curing regimes, splitting tensile strength, flexural strength, MOE, and water absorption.

\section{EXPERIMENTAL PROGRAM}

\subsection{Materials and Properties}

This experiment used ordinary Portland cement (OPC) with a specific gravity of 3.14 and Blaine surface area of $0.351 \mathrm{~cm} 2 / \mathrm{g}$. Sika Viscocrete2199, a superplasticizer are used in all mixes.

Local mining sand was used as fine aggregate with a fineness modulus of 2.33 , specific gravity of 2.63, and maximum nominal size of $2.36 \mathrm{~mm}$. Crushed granite from Kajang, OPBC from Dengil, and imported LECA were used as coarse aggregate. Table 1 and Figure 1 show the physical properties and sieve analysis grading curve, respectively, of crushed granite, OPBC, and LECA. The OPBC and LECA were used as substitutes for crushed granite. All types of coarse aggregates were used under SSD condition. Figure 2 shows the coarse aggregates of (a) LECA, (b) crushed granite, and (c) OPBC.

Table.1 Physical properties of the crushed granite, OPBC, and LECA

\begin{tabular}{|c|c|c|c|}
\hline $\begin{array}{c}\text { Physical } \\
\text { property }\end{array}$ & $\begin{array}{c}\text { Crushed } \\
\text { granite }\end{array}$ & OPBC & LECA \\
\hline $\begin{array}{c}\text { Specific } \\
\text { gravity }\end{array}$ & 2.67 & 1.90 & 0.66 \\
\hline Fineness & 5.54 & 5.88 & 5.96 \\
\hline $\begin{array}{c}\text { Bulk } \\
\text { density } \\
\text { (compacted) }\end{array}$ & $\begin{array}{c}1491 \\
\mathrm{~kg} / \mathrm{m}^{3}\end{array}$ & $\begin{array}{c}1471 \\
\mathrm{~kg} / \mathrm{m}^{3}\end{array}$ & $\begin{array}{c}810 \\
\mathrm{~kg} / \mathrm{m}^{3}\end{array}$ \\
\hline $\begin{array}{c}\text { Water } \\
\text { absorption } \\
\text { (24 hours) } \\
\text { \% }\end{array}$ & $0.62 \%$ & $3.91 \%$ & $26.5 \%$ \\
\hline \multicolumn{2}{|c|}{} & & \\
\hline
\end{tabular}

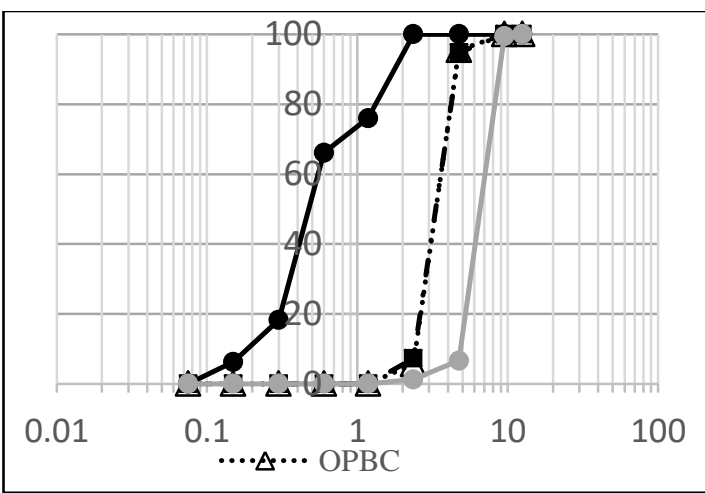

Fig. 1. Sieve analysis grading curve

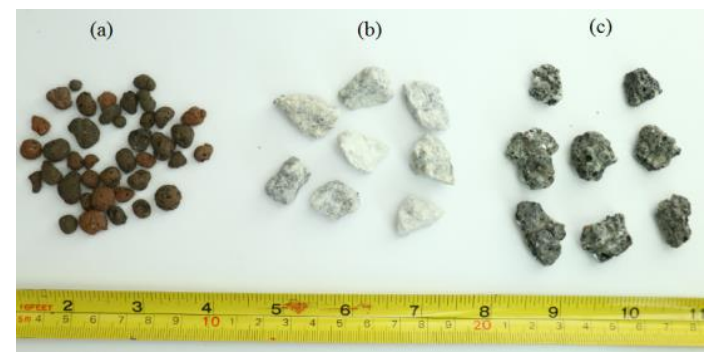

Fig. 2. Coarse aggregate of (a) LECA, (b) crushed granite, and (c) OPBC.

\subsection{Mix Proportions}

For comparison, a normal weight concrete with crushed granite as control mix (mix CM) was designed for grade 70 with high workability to investigate the effect of the substitution of normal weight coarse aggregate between OPBC and LECA on their engineering properties. A total of nine concrete mixes were prepared for this study. In this mix CM, normal weight coarse aggregate (granite) was substituted with OPBC (mix group A) and LECA (mix group B) from $0 \%$ to $100 \%$ by volume in increments of $25 \%$. The design of LWAC mixes is developed by trial (Shetty 2005). In this method, all of the mixes have the same mix proportions while containing different types of coarse aggregates. Given that LECA aggregate is round with the lowest weight compared with crushed granite and OPBC aggregate, high slump of LECA LWAC (B75 and B100) were found to easily cause floating of aggregate. Figure 1 shows the shapes of LECA, crushed granite, and OPBC. Superplastisizer, the dosage of which was reduced to approximately $16 \%$, was used in these two mixes to overcome the high slump. Table 2 shows the mix proportions of the nine concrete mixes. Basri et al. (1999) and Okafor (1988) claimed that the workability of a mixture is also dependent on the 
surface texture of aggregate from waste materials. 
Table 2 Mix proportions in one batch

\begin{tabular}{|c|c|c|c|c|c|c|c|c|c|}
\hline \multirow{2}{*}{$\begin{array}{l}\text { Mix } \\
\text { group }\end{array}$} & \multirow{2}{*}{$\begin{array}{l}\text { Mix } \\
\text { code }\end{array}$} & \multirow{2}{*}{$\begin{array}{l}\text { Cement } \\
\left(\mathrm{Kg} / \mathrm{m}^{3}\right)\end{array}$} & \multirow{2}{*}{$\begin{array}{l}\text { Water } \\
\left(\mathrm{Kg} / \mathrm{m}^{3}\right)\end{array}$} & \multirow{2}{*}{$\begin{array}{c}\text { Super } \\
\text { Plasticize } \\
\mathrm{r} \\
\left(\mathrm{Kg} / \mathrm{m}^{3}\right)\end{array}$} & \multirow{2}{*}{$\begin{array}{c}\begin{array}{c}\text { Fine } \\
\text { aggregate }\end{array} \\
\text { Sand } \\
\left(\mathrm{Kg} / \mathrm{m}^{3}\right)\end{array}$} & \multicolumn{3}{|c|}{ Coarse aggregate } & \multirow{2}{*}{$\begin{array}{l}\text { Replacing } \\
\text { percentage } \\
(\%)\end{array}$} \\
\hline & & & & & & $\begin{array}{l}\text { Granite } \\
\left(\mathrm{Kg} / \mathrm{m}^{3}\right)\end{array}$ & $\begin{array}{c}\text { OPBC } \\
\left(\mathrm{Kg} / \mathrm{m}^{3}\right)\end{array}$ & $\begin{array}{l}\text { Leca } \\
(\mathrm{Kg} / \\
\left.\mathrm{m}^{3}\right)\end{array}$ & \\
\hline $\begin{array}{c}\text { Control } \\
\text { mix }\end{array}$ & $\mathrm{CM}$ & 63.30 & 20.30 & 0.63 & 112.3 & 112.3 & 0 & 0 & 0 \\
\hline \multirow{4}{*}{$\begin{array}{c}\text { Group } \\
\text { A }\end{array}$} & A25 & 63.30 & 20.30 & 0.63 & 112.3 & 84.3 & 20 & 0 & 25 \\
\hline & A50 & 63.30 & 20.30 & 0.63 & 112.3 & 56.2 & 40 & 0 & 50 \\
\hline & A75 & 63.30 & 20.30 & 0.63 & 112.3 & 28.1 & 60 & 0 & 75 \\
\hline & A100 & 63.30 & 20.30 & 0.63 & 112.3 & 0 & 80 & 0 & 100 \\
\hline \multirow{4}{*}{$\begin{array}{c}\text { Group } \\
\text { B }\end{array}$} & B25 & 63.30 & 20.30 & 0.63 & 112.3 & 84.2 & 0 & 7 & 25 \\
\hline & B50 & 63.30 & 20.30 & 0.63 & 112.3 & 56.2 & 0 & 14 & 50 \\
\hline & B75 & 63.30 & 20.30 & 0.53 & 112.3 & 28.1 & 0 & 20.9 & 75 \\
\hline & B100 & 63.30 & 20.30 & 0.53 & 112.3 & 0 & 0 & 28.1 & 100 \\
\hline
\end{tabular}

\subsection{Mixing Procedure and Concrete Casting}

The mixing procedures are as bellow's steps:

Step 1: Place aggregates into a rotary drumtype mixer and mix for 2 minutes.

Step 2: Add cement and mix for 3 minutes.

Step 3: Add $70 \%$ of mixing water into the mixer and mix for another 3 minutes.

Step 4: Add balance to the mixing water with superplasticizer into the mixer and mix for 5 minutes.

Step 5: Perform consistency test.

The consistency test confirmed that the workability of concrete reached a satisfactory level. The concrete specimens were cast in steel molds of $100 \mathrm{~mm}$ cubes for compressive strength, cylinders of $100 \mathrm{~mm}$ diameter and 200 $\mathrm{mm}$ height for splitting tensile strength, prisms of $100 \mathrm{~mm} \times 100 \mathrm{~mm} \times 500 \mathrm{~mm}$ for flexural strength, and cylinders of $150 \mathrm{~mm}$ diameter and $200 \mathrm{~mm}$ height for MOE. All specimens were compacted using a vibrating table. The results correspond to the mean values of at least three specimens for mechanical properties.

\subsection{Curing Regimes}

The following tests have been conducted under five curing conditions after 24 hours of casting to investigate the impacts of different curing regimes on the 28-day compressive strength.

(1) Continuous water curing (FW): Specimen was soaked in water with temperature of $23 \pm$ $3{ }^{\circ} \mathrm{C}$ for 27 days after 1 day of demolding.
(2) Air drying (AC): Specimen was placed under laboratory condition with RH\% of $73 \pm$ 5 and temperature of $29 \pm 3{ }^{\circ} \mathrm{C}$ after 1 day of demolding.

(3) 3 days ( $3 \mathrm{~W}), 5$ days $(5 \mathrm{~W})$, and 7 days (7W) of partial early curing: Specimen was soaked in water for 2,4 , and 6 days after 1 day of demolding and then put in air under laboratory condition.

\section{RESULTS AND DISCUSSION}

\subsection{Workability}

Table 3 depicts the slump values and densities of all mixes. The slump values of the mixes of groups $\mathrm{A}$ and $\mathrm{B}$ decreased while increasing the OPBC and LECA aggregates, respectively. This result can be attributed to the condition in which the water absorption of OPBC and LECA aggregates are more significant than that of crushed granite by 6 times and 43 times, respectively. The surfaces of these lightweight aggregates are porous. Thus, part of cement paste, which is absorbed into the grain, reduced the workability. By increasing the amount of OPBC and LECA aggregates and reducing crushed granite in the concrete mixture, the slump value decreased. However, the reductions of the slump values for the mixes of groups A and B are insignificant with substitution of the amount of OPBC and LECA aggregates, respectively. 
Table 3. The slump and density of concrete

\begin{tabular}{|c|c|c|c|c|c|c|}
\hline Mix group & \multirow{2}{*}{$\begin{array}{c}\text { Mix } \\
\text { code }\end{array}$} & $\begin{array}{c}\text { Slump } \\
(\mathrm{mm})\end{array}$ & \multicolumn{4}{|c|}{ Density $\left(\mathrm{Kg} / \mathrm{m}^{3}\right)$} \\
\cline { 4 - 7 } & & & Demould & $\begin{array}{c}\text { Air dry at } 28 \\
\text { days }\end{array}$ & $\begin{array}{c}\text { Saturated at 28 } \\
\text { days }\end{array}$ & $\begin{array}{c}\text { Oven dry at 28 } \\
\text { days }\end{array}$ \\
\hline Control mix & CM & 105 & 2356 & 2317 & 2370 & 2294 \\
\hline \multirow{3}{*}{ Group A } & A25 & 95 & 2148 & 2126 & 2159 & 2232 \\
\cline { 2 - 7 } & A50 & 80 & 2200 & 2191 & 2220 & 2178 \\
\cline { 2 - 7 } & A75 & 70 & 2290 & 2261 & 2303 & 2106 \\
\cline { 2 - 7 } & A100 & 55 & 2076 & 2057 & 2121 & 1905 \\
\hline \multirow{3}{*}{ Group B } & B25 & 90 & 2147 & 2132 & 2169 & 2098 \\
\cline { 2 - 7 } & B50 & 85 & 1937 & 1893 & 1960 & 1879 \\
\cline { 2 - 7 } & B75 & 70 & 1736 & 1703 & 1774 & 1693 \\
\cline { 2 - 7 } & B100 & 50 & 1550 & 1510 & 1603 & 1507 \\
\hline
\end{tabular}

The CM and all LWACs (mixes of groups A and B) confirmed acceptable workability. Mehta and Monteiro (2006) revealed that in general site application, the slump value of LWAC in the range of 50 to $75 \mathrm{~mm}$ is equivalent to that of 100 to $125 \mathrm{~mm}$ of normal weight concrete. Previous studies showed that OPBC concrete with 28-day compressive strength in the range of 17 to 47 $\mathrm{MPa}$ has a slump value of 45 to $190 \mathrm{~mm}$ (Abdullahi et al. 2008; Mohammed et al. 2013, 2014), whereas compressive strength of 27 to $35.5 \mathrm{MPa}$ has slump values of $40-100 \mathrm{~mm}$ (Hassan et al. 2008). However, LECA LWAC with the compressive strength of $37.46 \mathrm{MPa}$ showed a slump value of $95 \mathrm{~mm}$ (Shafigh et al. 2012a), whereas compressive strength ranging from 34.7 to $63.9 \mathrm{MPa}$ showed a slump value of 110 to $140 \mathrm{~mm}$ (Lo et al. 2008).

\subsection{Density}

Table 3 shows that the oven dry density decreased by $2.7 \%$ to $17 \%$ through increasing the substitution of OPBC in the mix CM from $25 \%$ to $100 \%$ in mix group A. However, for mix group B, the oven dry density decreased by $8.5 \%$ to $34.3 \%$ because the weight of OPBC aggregate is approximately $65 \%$ higher than that of LECA aggregate. The OPBC and the LECA are approximately $29 \%$ and $75 \%$ lighter than crushed granite, respectively. Therefore, the substitution of crushed granite with the OPBC and the LECA are expected to reduce the density of normal-weight concrete ( $\mathrm{mix} \mathrm{CM}$ ). As a comparison between the LWAC-containing OPBC (mix group A) and the LECA (mix group $\mathrm{B}$ ), the oven dry density of mix group $\mathrm{A}$ is considerably higher than that of mix group $\mathrm{B}$
Figure 3 depicts a strong linear relationship between the oven dry density and percentage substitution of the OPBC (mix group A), the LECA (mix group B), and the OPS (Shafigh et al. 2012b). In the comparison among mix group A, mix group B, and OPS concrete, the oven dry density of OPS concrete is substantially lower than that of mix group A while higher than that of mix group B from the substitution of $25 \%$ onwards. This result is due to the fact that the weight of the OPS grain is nearly half of the OPBC grain while $44 \%$ higher than that of the LECA.

According to BS EN 206-1, the category of lightweight concrete is defined in the range of 800 and 2,000 kg/m3 (BSI 1992). Therefore, the oven 'dry density of concrete containing 100\% OPBC (mix A100) and 50\% LECA onwards (mixes of B50, B75, and B100) in this study can be considered as lightweight concrete. 


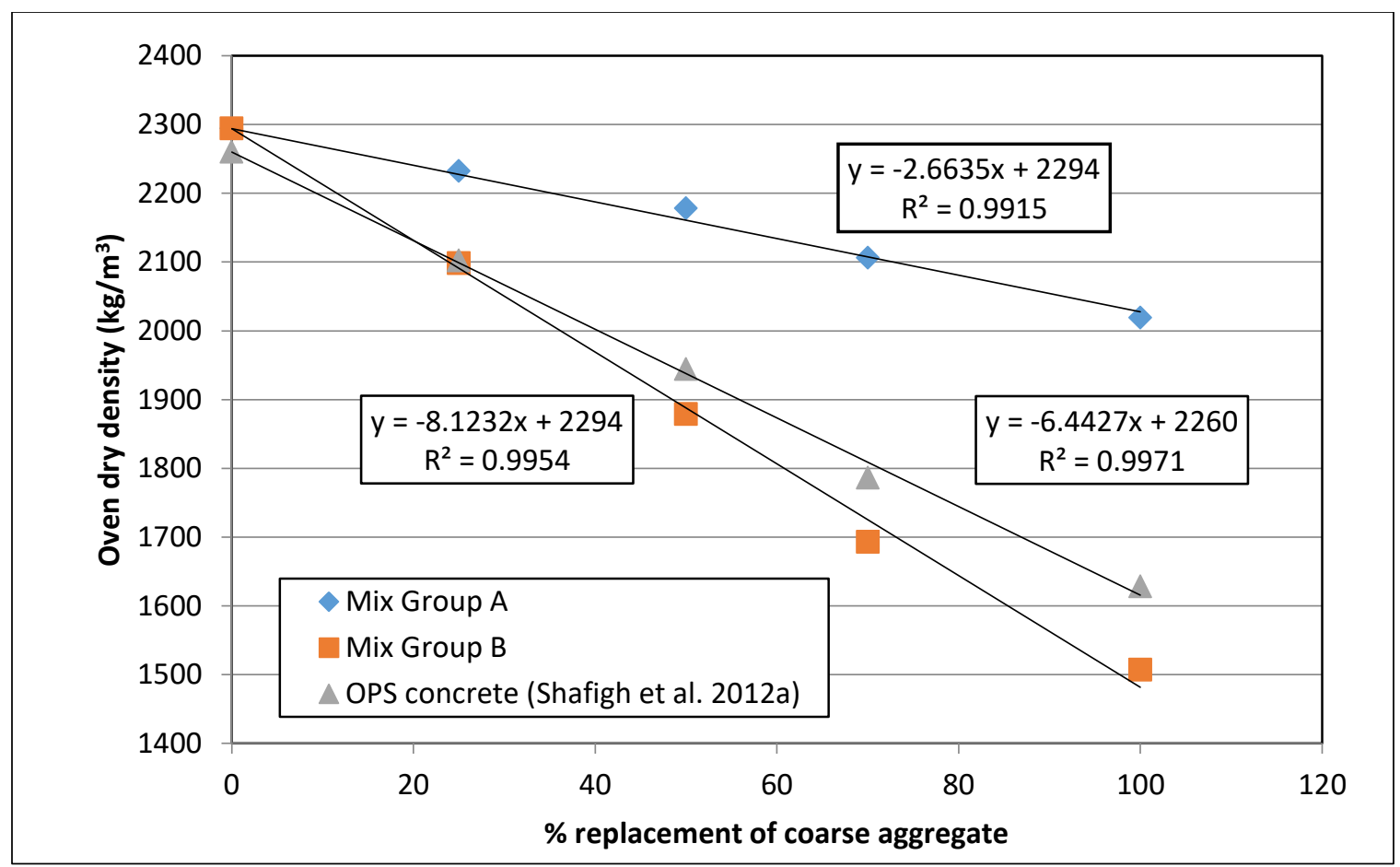

Fig.3. Relationship between density and percentage replacement of normal coarse aggregate by OPBC, LECA and OPS.

\subsection{Compressive Strength}

\subsubsection{Under Continuous Water Curing}

Table 4 shows the compressive strength of the full water-cured concrete of up to 56 days. The development of strength at 1st, 3rd, 7th, 28th, and 56th days of testing were almost the same patterns in all mixes. With the increasing age of concrete, the compressive strengths of all mixes increase. Mix CM exhibited the highest values of compressive strength compared with OPBC concrete (mix group A) and LECA concrete (mix group B). However, among the three mix groups, the LECA concrete (mix group B) showed the lowest compressive strength because LECA is the weakest aggregate whereas OPBC is weaker than crushed granite. The amount of improvement in compressive strength of mix group B (containing LECA) showed higher than that of mix group A (containing OPBC) in all ages. The compressive strengths at the age of 28 days of OPBC concrete (mix group A) and LECA concrete (mix group B) are approximately 5 to $22 \%$ and 42 to $79 \%$ lower than normal weight concrete $(\mathrm{CM})$, respectively.

The use of $25 \%$ (mix A25) and 50\% (mix A50) substitution percentage of OPBC in normalweight concrete illustrated that the compressive strengths of both mixes were almost the same in all ages. In addition, the concrete containing $75 \%$ (mix A75) OPBC also confirmed that the compressive strength was similar to that of mix A100 mix in all ages. However, the rate of increasing the compressive strength of mix A75 mix onward was higher than that of mixes of A25 and A50 mixes in all ages. This result can be attributed to the fact that the OPBC aggregate is a more porous aggregate compared with crushed granite, as shown in Figure 1. As the cement mortar was absorbed into the porosity of the OPBC grain, the effective water-to-cement ratio decreased; therefore, the strength of the OPBC mixture increased.

The LECA-containing concrete containing up to $25 \%$ LECA of (mix B25) was substituted by normal-weight coarse aggregate. The compressive strengths at the ages of 3 days and 7 days were similar to the 28-day compressive strength. Furthermore, the inclusion of concrete with $25 \%$ and $100 \%$ LECA content in normalweight concrete reached almost the same strength as 28-day compressive strength at the age of 7 days in this mix. Shafigh et al. (2014) and Mahmud et al. (2013) reported that the ceiling strength of LECA-containing concrete was at the early age of 7 days. The ceiling strength in the rest of the mixtures was not observed at this age. Ceiling strength point is 
largely determined by the grain of coarse aggregate and the quality of transition zone (Holm and Bremner 2000). Furthermore, the ceiling strength of concrete also depends on the type of aggregate used in the mixture (Clarke 1993). Lamond and Pielert (2006) reported that the strength of lightweight concrete would not be significantly improved by adding cementitious materials at the ceiling strength point of the mixture.
In addition, 7-day compressive strength of concrete containing the OPBC (mix group A) and the LECA (mix group B) is at approximately 81 to $88 \%$ and 90 to $99 \%$ that of 28-day compressive strength, respectively. Previous reports revealed that the 7-day compressive strength of the OPBC and the LECA, could reach up to 80 to $92 \%$ (Fujji et al. 1998; Omar and Mohamed, 2002) and 80 to $95 \%$ of 28-day compressive strength (CEB/FIP 1977), respectively.

Table 4 Compressive strength under full water curing

\begin{tabular}{|c|c|c|c|c|c|c|}
\hline Mix group & Mix code & 1 day & 3 days & 7 days & 28 days & 56 days \\
\hline Control mix & CM & $\begin{array}{c}30.15 \\
(43 \%)\end{array}$ & $\begin{array}{c}55.60 \\
(78 \%)\end{array}$ & $\begin{array}{c}55.98 \\
(79 \%)\end{array}$ & 70.94 & $\begin{array}{c}76.01 \\
(107 \%)\end{array}$ \\
\hline \multirow{6}{*}{ Group A } & A25 & $\begin{array}{c}28.50 \\
(42 \%)\end{array}$ & $\begin{array}{c}50.51 \\
(75 \%)\end{array}$ & $\begin{array}{c}54.48 \\
(81 \%)\end{array}$ & 67.52 & $\begin{array}{c}71.89 \\
(106 \%)\end{array}$ \\
\cline { 2 - 7 } & A50 & $\begin{array}{c}29.50 \\
(45 \%)\end{array}$ & $\begin{array}{c}49.93 \\
(76 \%)\end{array}$ & $\begin{array}{c}53.50 \\
(81 \%)\end{array}$ & 65.70 & $\begin{array}{c}70.30 \\
(107 \%)\end{array}$ \\
\cline { 2 - 7 } & $\mathrm{A} 75$ & $\begin{array}{c}27.97 \\
(50 \%)\end{array}$ & $\begin{array}{c}44.49 \\
(80 \%)\end{array}$ & $\begin{array}{c}47.70 \\
(86 \%)\end{array}$ & 55.46 & $\begin{array}{c}58.79 \\
(106 \%)\end{array}$ \\
\cline { 2 - 7 } & $\mathrm{A} 100$ & $\begin{array}{c}26.01 \\
(47 \%)\end{array}$ & $\begin{array}{c}44.84 \\
(81 \%)\end{array}$ & $\begin{array}{c}48.36 \\
(88 \%)\end{array}$ & 55.00 & $\begin{array}{c}57.68 \\
(105 \%)\end{array}$ \\
\hline \multirow{5}{*}{ Group B } & $\mathrm{B} 25$ & $\begin{array}{c}30.10 \\
(73 \%)\end{array}$ & $\begin{array}{c}40.27 \\
(97 \%)\end{array}$ & $\begin{array}{c}41.16 \\
(99 \%)\end{array}$ & 41.39 & $\begin{array}{c}42.32 \\
(102 \%)\end{array}$ \\
\cline { 2 - 7 } & $\mathrm{B} 50$ & $\begin{array}{c}18.15 \\
(54 \%)\end{array}$ & $\begin{array}{c}27.41 \\
(82 \%)\end{array}$ & $\begin{array}{c}30.09 \\
(90 \%)\end{array}$ & 33.43 & $\begin{array}{c}35.46 \\
(106 \%)\end{array}$ \\
\cline { 2 - 7 } & $\mathrm{B} 75$ & $\begin{array}{c}14.32 \\
(63 \%)\end{array}$ & $\begin{array}{c}18.71 \\
(82 \%)\end{array}$ & $\begin{array}{c}20.99 \\
(92 \%)\end{array}$ & 22.82 & $\begin{array}{c}24.095 \\
(105 \%)\end{array}$ \\
\cline { 2 - 7 } & $\mathrm{B} 100$ & $\begin{array}{c}11.43 \\
(76 \%)\end{array}$ & $\begin{array}{c}13.80 \\
(92 \%)\end{array}$ & $\begin{array}{c}15.02 \\
(99 \%)\end{array}$ & 15.08 & $\begin{array}{c}16.08 \\
(107 \%)\end{array}$ \\
\hline
\end{tabular}

\subsubsection{Under AC and Partial Early Curing Conditions}

Table 5 shows the compressive strength of all mixes under different curing conditions (AC, $3 \mathrm{~W}, 5 \mathrm{~W}$, and $7 \mathrm{~W}$ ) at the age of 28 days. The compressive strength of the mixes of $\mathrm{CM}$, group $\mathrm{A}$, and group B under AC condition was reduced by approximately $7 \%, 3$ to $10 \%$ and 7 to $12 \%$ as compared with those of specimens under FW condition, respectively. The reduction of the compressive strength in mix group B (LECAcontaining concrete) is the lowest compared with those of mix CM and mix group A (concretecontaining OPBC). The reason could be that the use of saturated LECA provided internal curing for the mixture which improved the strength by allowing continuous hydration in concrete (Mather 2001; Bentz et al. 2005; Wang et al. 1994; Dhir et al. 1994). However, the saturated LECA depicted higher sensitivity to the lack of curing compared with crushed granite and OPBC. By contrast, the reduction of compressive strength in mix group $\mathrm{A}$ is lower than the mix CM. The use of saturated OPBC as partial or full replacement of crushed granite resulted in reduction of the sensitivity of normal-weight concrete under poor curing condition. As the OPBC aggregate is highly porous with absorbed part of water during mixing process, the effective water-cement ratio of concrete may decrease. The reduction in water-cement ratio in mix Group A can lead to an increase in the compressive strength of concrete. Therefore, the existing reserved water inside the OPBC aggregate provided internal curing to the concrete. Bentz et al. (2005) reported that the acceleration of hydration and increasing the strength of concrete can be achieved by using saturated lightweight aggregate to provide additional existing reserved water to the mixture. The compressive strength in LECA-containing 
concrete (mix group B) of this study is the lowest among all mixes under $\mathrm{AC}$ and partial early curing conditions because LECA is weakest and has the highest porosity compared with crushed granite and OPBC.

The 28-day compressive strength of all mixes under partial early curing regime is expected to be higher than those of the corresponding specimens under AC. This result may be due to the fact that FW promoted a high amount of hydration leading to high compressive strength in concrete under partial early curing while a low amount of hydration led to low compressive strength of concrete under AC condition. The rate of improvement of the 28-day compressive strength under $3 \mathrm{~W}, 5 \mathrm{~W}$, and $7 \mathrm{~W}$ was 1 to $4 \%, 10$ to $16 \%$, and 12 to $25 \%$ for mix group A while 0 to $14 \%, 5$ to $34 \%$, and 5 to $42 \%$ for mix group B, respectively, compared with that of $\mathrm{AC}$ condition. The amount of compressive strength gained under $5 \mathrm{~W}$ and $7 \mathrm{~W}$ of the two types of mixtures was higher than that under $3 \mathrm{~W}$ curing regime. The 28-day compressive strength of $5 \mathrm{~W}$ was close to that of $7 \mathrm{~W}$ regime condition for both mix groups. Furthermore, the amount of improvement in compressive strength under partial curing of mix Group B (LECA-containing concrete) was higher than that of mix group A (OPBC-containing concrete) because the porosity of LECA is higher than that of OPBC. Cusson et al. (2005), Bentz et al. (2004, 2005), and Jensen and Hansen (2001) reported that the water stored inside saturated LECA particles can provide continuous hydration by producing cement paste to fill up voids and create a strong bonding force between an aggregate and cement paste.

In the 28-day compressive strength under the partial early curing regimes of $3 \mathrm{~W}$, the compressive strength was almost the same or even higher than that of standard curing in all mixes, except of mixes of B75 and B100. For both $5 \mathrm{~W}$ and $7 \mathrm{~W}$ curing conditions, the compressive strengths of mixes of CM, Group A, B25, and B50 were slightly greater than that of standard curing, while it was slightly lower for mixes of B75 and B100. Haque (1990) recommended that a minimum of 7 days of moist curing shall be practiced in all concreting works.

Table 5. The compressive strength of concrete at the age of 28 days under different curing regimes

\begin{tabular}{|c|c|c|c|c|c|c|}
\hline \multirow{3}{*}{ Mix group } & \multicolumn{6}{|c|}{ The compressive strength at the age of 28 days (MPa) } \\
\hline & \multirow{2}{*}{$\begin{array}{l}\text { Mix } \\
\text { code }\end{array}$} & \multirow{2}{*}{$\begin{array}{l}\text { Standard curing } \\
\text { condition }(\mathrm{FW})\end{array}$} & \multicolumn{4}{|c|}{ Partial early curing } \\
\hline & & & $\mathrm{AC}$ & $3 \mathrm{~W}$ & $5 \mathrm{~W}$ & $7 \mathrm{~W}$ \\
\hline Control mix & $\mathrm{CM}$ & 70.94 & 65.70 & 67.79 & 77.64 & 78.56 \\
\hline \multirow{4}{*}{ Group A } & $\mathrm{A} 25$ & 67.52 & 65.67 & 67.82 & 73.89 & 75.96 \\
\hline & A50 & 65.70 & 62.94 & 65.69 & 69.05 & 70.50 \\
\hline & A75 & 59.46 & 57.83 & 58.50 & 63.50 & 64.97 \\
\hline & A100 & 55.00 & 49.60 & 50.20 & 57.80 & 62.10 \\
\hline \multirow{4}{*}{ Group B } & B25 & 41.39 & 36.26 & 41.50 & 48.51 & 51.42 \\
\hline & B50 & 33.43 & 29.42 & 33.01 & 35.13 & 35.17 \\
\hline & B75 & 22.82 & 20.12 & 21.01 & 21.40 & 21.46 \\
\hline & B100 & 15.08 & 14.05 & 14.07 & 14.75 & 14.73 \\
\hline
\end{tabular}

\subsection{Splitting Tensile Strength and Flexural Strength}

Tables 6 and 7 show the splitting tensile strength and flexural strength for all mixes. As can be seen the concretes containing OPBC (mix group A) and LECA (mix group B) have lower splitting tensile strength and flexural strength than normal-weight concrete (mix CM). The mixes subjected to water curing showed higher splitting tensile strength and flexural strength compared with those under the $\mathrm{AC}$ condition at the age of 28 days. As expected, continuous hydration under FW could improve the strength of all mixes. In addition, the amounts of differences between $\mathrm{AC}$ and $\mathrm{FW}$ conditions for splitting tensile strength and flexural strength were 7 to $16 \%$ and 3 to $11 \%$ for mix group A whereas they were 5 to $25 \%$ and 5 to $19 \%$ for mix group B, respectively. Compared with compressive strength, the splitting tensile strength and flexural strength for mixes of groups A and B were found to be more sensitive to poor curing regimes. 
The requirement of splitting tensile strength at the age of 28 days should be more than $2.0 \mathrm{MPa}$ for structural lightweight concrete members (Kockal and Ozturan 2011; ASTM: C330 2005). The splitting tensile strength of the present study showed more than 2.0 MPa at 7- and 28-day ages. Therefore, all these mixtures at 7 days can be recommended for constructing structural concrete components.

The splitting tensile strength-compressive strength ratio at the ages of 28 days for normalweight concrete is within the range of 8 to $14 \%$ (Kosmatka and Wilson 2011). This ratio for high-strength lightweight concrete under FW is in the range of 6 to $7 \%$ (Holm and Bremner 2000). The ratios of 28-day splitting tensile strength/compressive strength of this study for mixes of groups A and B were 6.9 to $7.5 \%$ and 8 to $14.9 \%$, respectively.

The amounts of improvement of splitting tensile strength from 7 to 28 days for Groups A and B were 8 to $23 \%$ and 1 to $8 \%$, respectively. However, the increases in compressive strength from 7 to 28 days were 12 to $19 \%$ and 1 to $10 \%$ for mixes of groups $\mathrm{A}$ and $\mathrm{B}$, respectively. Therefore, the amount of rate increase in splitting tensile strength and compressive strength with time for mix group $\mathrm{A}$ is more critical than mix group B.

Figure 4 shows the 28-day splitting tensile strength under $\mathrm{AC}, 7 \mathrm{~W}$, and $\mathrm{FW}$ conditions of all mixes. The figure shows that the slope of mix group B was more than that for mix group A. This result confirmed that the reduction rate in mix group B was more than that of mix group A. The negative effect of the substitution of LECA was more affirmed than the substitution of OPBC in normal-weight concrete.

Shetty (2005) revealed that flexural strengthcompressive strength ratio for concrete with a compressive strength of not less than $25 \mathrm{MPa}$ exhibited between 8 to $10 \%$. Domagała (2011) reported that flexural strength-compressive strength ratio for lightweight concrete is lower than that of normal weight concrete. Omar and Mohamed (2002) also revealed that flexural strength-compressive strength ratio for highstrength lightweight concrete is in the range of 9 to $11 \%$. As shown in Table 7 , the flexural strength-compressive strength ratio of mixes of groups $\mathrm{A}$ and $\mathrm{B}$ is in the range of 8.6 to $10.1 \%$ and 12.3 to $21.6 \%$, respectively.

Generally, the flexural strength is $35 \%$ higher than splitting tensile strength (Zheng et al. 2001). However, the flexural strength in this study is 16 to $37 \%$ and 38 to $53 \%$ higher than the splitting tensile strength for mixes of groups $\mathrm{A}$ and $\mathrm{B}$, respectively.

Figure 5 shows that incorporating OPBC and LECA in normal weight concrete reduces the flexural strength because the two mixtures are porous aggregates. OPBC and LECA are weaker than crushed granite. However, the results show that the rate of reduction in mix group B (LECAcontaining concrete) is higher than that of mix group A (OPBC-containing concrete) because LECA is lighter and weaker than OPBC.

Table 6. Splitting tensile strength of concrete mixes (MPa).

\begin{tabular}{|c|c|c|c|c|c|}
\hline \multirow{3}{*}{ Mix group } & \multirow{3}{*}{$\begin{array}{l}\text { Mix } \\
\text { code }\end{array}$} & \multicolumn{2}{|c|}{ Splitting tensile strength } & \multicolumn{2}{|c|}{ 28-day splitting tensile strength } \\
\hline & & \multicolumn{2}{|c|}{ Water curing } & \multicolumn{2}{|c|}{ Partial early curing } \\
\hline & & 7 days & 28 days & Air curing & $7 \mathrm{~W}$ \\
\hline Control mix & $\mathrm{CM}$ & 3.73 & 5.19 & 4.72 & 4.89 \\
\hline \multirow{4}{*}{ Group A } & $\mathrm{A} 25$ & 3.70 & 5.03 & 4.66 & 4.78 \\
\hline & A50 & 3.68 & 4.90 & 4.14 & 4.43 \\
\hline & A75 & 3.63 & 4.06 & 3.86 & 3.89 \\
\hline & A100 & 3.36 & 3.79 & 3.40 & 3.60 \\
\hline \multirow{4}{*}{ Group B } & B25 & 3.16 & 3.33 & 3.15 & 3.28 \\
\hline & B50 & 3.05 & 3.19 & 2.39 & 3.16 \\
\hline & $\mathrm{B} 75$ & 2.43 & 2.53 & 2.14 & 2.42 \\
\hline & B100 & 2.15 & 2.24 & 1.86 & 2.15 \\
\hline
\end{tabular}


Table 7. Flexural strength of concrete mixes (MPa)

\begin{tabular}{|c|c|c|c|c|c|c|}
\hline \multirow{2}{*}{ Mix group } & Mix code & $\left(f_{c u}\right)$ & $\left(f_{r, A C}\right)$ & $\left(f_{r}\right)$ & $\left(\frac{f_{r}}{f_{c u}}\right) \%$ & $\left(\frac{f_{r}}{f_{t}}\right)$ \\
\hline Control mix & $\mathrm{CM}$ & 70.94 & 5.95 & 6.31 & 8.9 & 1.16 \\
\hline \multirow{3}{*}{ Group A } & $\mathrm{A} 25$ & 67.52 & 5.59 & 5.83 & 8.6 & 1.16 \\
\cline { 2 - 7 } & $\mathrm{A} 50$ & 65.70 & 5.56 & 5.77 & 8.8 & 1.18 \\
\cline { 2 - 7 } & $\mathrm{A} 75$ & 55.46 & 5.11 & 5.58 & 10.1 & 1.37 \\
\cline { 2 - 7 } & $\mathrm{A} 100$ & 55.00 & 4.70 & 5.31 & 9.7 & 1.37 \\
\hline \multirow{3}{*}{ Group B } & $\mathrm{B} 25$ & 41.39 & 4.42 & 5.09 & 12.3 & 1.53 \\
\cline { 2 - 7 } & $\mathrm{B} 50$ & 33.43 & 4.28 & 4.50 & 13.5 & 1.41 \\
\cline { 2 - 7 } & $\mathrm{B} 75$ & 22.82 & 2.94 & 3.49 & 15.3 & 1.38 \\
\cline { 2 - 7 } & $\mathrm{B} 100$ & 15.08 & 2.63 & 3.25 & 21.6 & 1.38 \\
\hline
\end{tabular}

*f_cu, f_(r,AC) f_r and f_t are 28-day compressive, flexural under AC condition, flexural and splitting tensile strengths $(\mathrm{MPa})$, respectively.

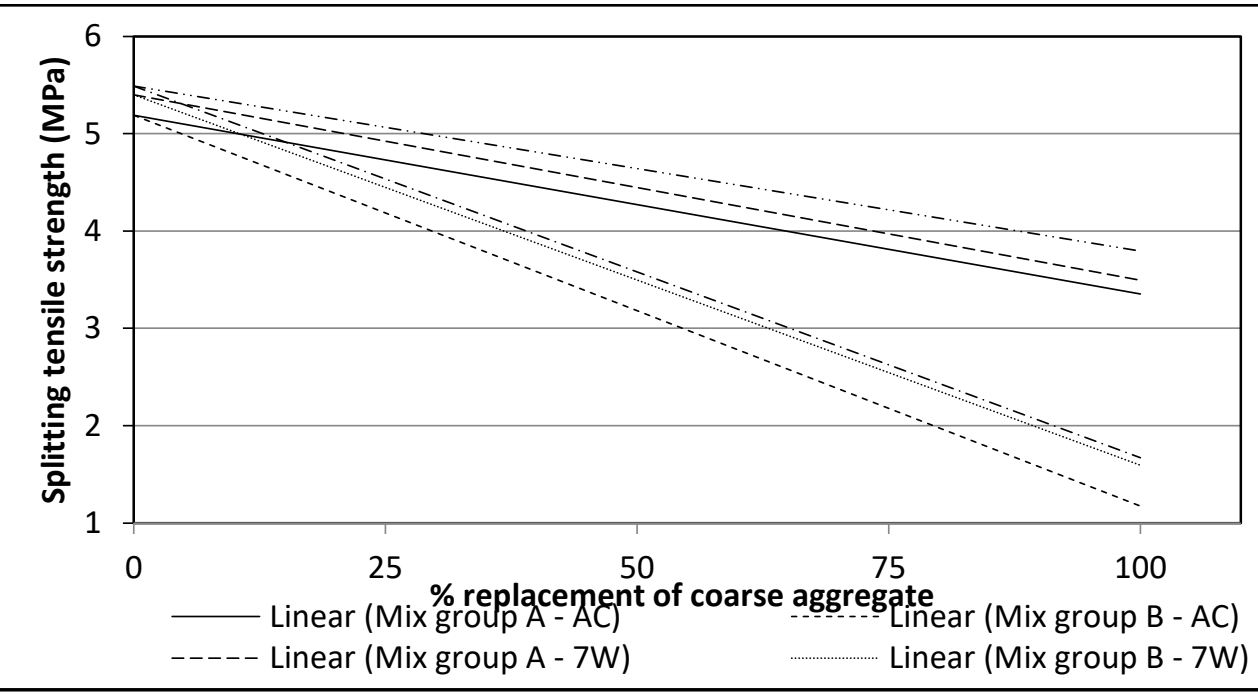

Fig.4 28-day splitting tensile strength under AC, 7W and FW condition

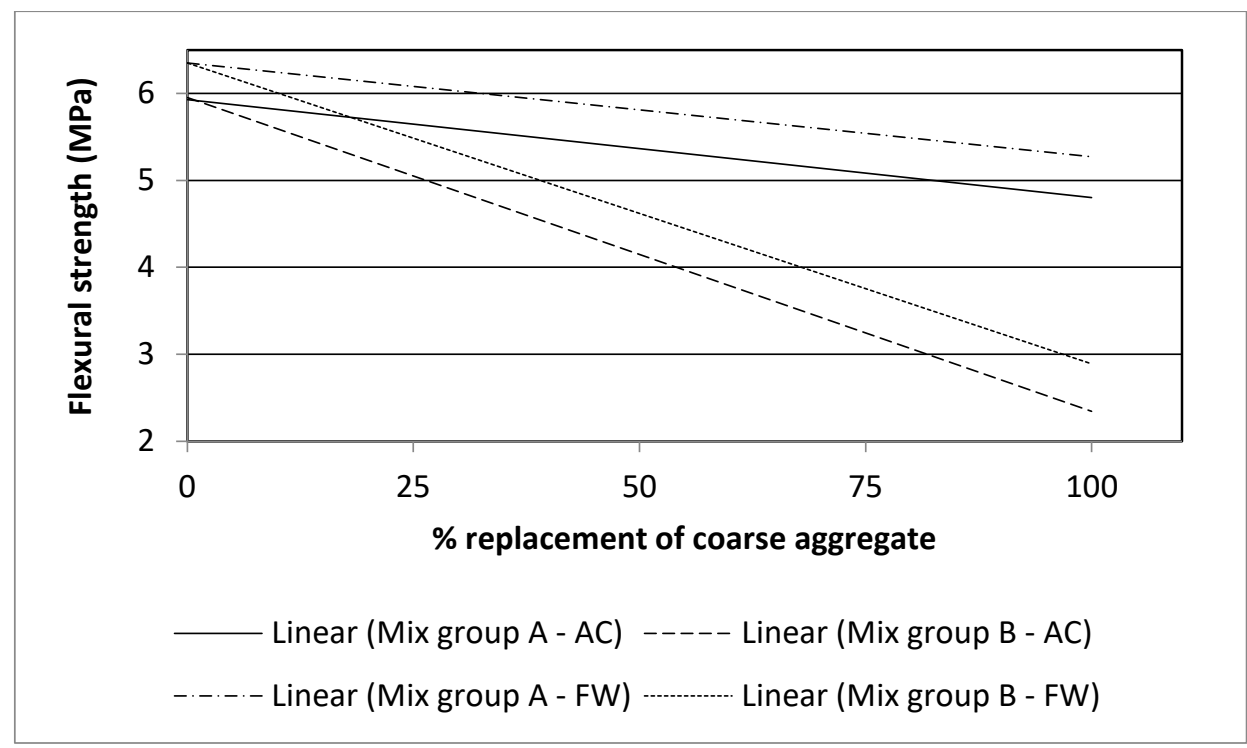

Fig.5. 28-day flexural strength under AC and FW condition 


\subsection{Modulus of Elasticity}

The modulus of elasticity (MOE) of all mixes are is shown in Table 8. The substitution of crushed granite with the OPBC (mix group A) and the LECA (mix group B) in normal-weight concrete reduced the MOE. By increasing the amount of substitution from 25 to $100 \%$ in both mixtures, the MOE was gradually reduced. The amounts of reductions of up to $29 \%$ and $54 \%$ were respectively found for mixes of groups $\mathrm{A}$ and $\mathrm{B}$ under AC condition, whereas $42 \%$ and $63 \%$ were observed for mixes of groups A and B under FW condition, respectively. However, the rate of reduction of mixture containing the LECA (mix group B) was higher than that of mixture containing the OPBC (mix group B). Therefore, the use of saturated LECA and OPBC in concrete could help in the continuous hydration of cement paste leading to the reduction in the porosity of concrete. However, the MOE of a mixture is largely dependent on the quality and the MOE of coarse aggregate instead of that of mortar. Caldarone (2009) reported that the MOE is dependent on the quality of coarse aggregate in the mixture. Thus, the MOE plays an important role in the mechanical properties of concrete.

According to the test results, regression analysis shows the relationship between the MOE and the compressive strength at 28 days, as expressed in Eq. (1) for the case of OPBC-containing LWAC (mix group A) and in Eq. (2) for the case of LECA-containing LWAC (mix group B).

$$
\begin{gathered}
E=0.067 f_{c u}{ }^{1.4958} \\
E=2.5528 f_{c u}{ }^{0.6708}
\end{gathered}
$$

where, $E$ is the $\operatorname{MOE}(\mathrm{GPa})$, and $f_{c u}$ is
(MPa). The degree of confidence is 0.95 in the case of OPBC-containing LWAC (mix group A) and 0.92 in the case of LECA-containing LWAC (mix group B), as shown in Figure 6.

Figure 7 shows the comparison of the MOE values of the mixes with those predicted by the different equations proposed by BS 8110 (1985) [Eq. (3)]; ACI 318 (1995) [Eq. (4)] for compressive strength of 21 to $35 \mathrm{MPa}$ with density in the range of 1440 to $2480 \mathrm{~kg} / \mathrm{m}^{3}$; Pauw (1960) [(Eq. (5)] who proposed a common estimating equation; Tasnimi (2004) [Eq. (6)] who reported artificial LWAC with cylinder compressive strength of 15 to $55 \mathrm{MPa}$; and Slate et al. (1986) [(Eq. (7)] who presented a highstrength lightweight concrete. The equations are expressed as follows:

$$
\begin{aligned}
& E=0.0017 w^{2} f_{c u}^{0.33} \\
& E=0.043 w^{1.5} f^{0.5} \\
& E=0.04 w^{1.5} f_{c u}^{0.5} \\
& E=2.1684 f^{0.535} \\
& E=\left(0.062+0.029 f^{0.5}\right) w^{1.5}
\end{aligned}
$$

where, $E$ is $\operatorname{MOE}(\mathrm{GPa}), w$ is air-dry density $\left(\mathrm{kg} / \mathrm{m}^{3}\right), f_{c u}$ is cube compressive strength (MPa), and $f$ is the cylinder compressive strength $(\mathrm{MPa})$.

Figure 7 shows that among all equations, Eqs. (3), (4), and (5) for compressive strength less than $65 \mathrm{MPa}$ and Eq. (7) for less than $55 \mathrm{MPa}$ of

\begin{tabular}{|c|c|c|c|}
\hline \multirow{2}{*}{$\begin{array}{l}\text { Mix } \\
\text { group }\end{array}$} & \multirow{2}{*}{$\begin{array}{l}\text { Mix } \\
\text { code }\end{array}$} & \multicolumn{2}{|c|}{ 28-day modulus of elasticity } \\
\hline & & Air curing & Water curing \\
\hline $\begin{array}{l}\text { Control } \\
\operatorname{mix}\end{array}$ & $\mathrm{CM}$ & 36.13 & 45.53 \\
\hline \multirow{4}{*}{$\begin{array}{c}\text { Group } \\
\text { A }\end{array}$} & A25 & 34.93 & 38.01 \\
\hline & A50 & 30.13 & 33.50 \\
\hline & A75 & 26.55 & 27.73 \\
\hline & A100 & 25.74 & 26.58 \\
\hline \multirow{4}{*}{$\begin{array}{c}\text { Group } \\
\text { B }\end{array}$} & $\mathrm{B} 25$ & 29.04 & 34.02 \\
\hline & B50 & 24.21 & 24.91 \\
\hline & B75 & 19.24 & 19.26 \\
\hline & B 100 & 16.75 & 16.76 \\
\hline
\end{tabular}
OPBC-containing LWAC provide accurate estimates of the MOE values. However, Eqs. (3), (4), (5), (6), and (7) for LECA-containing LWAC underestimate the MOE values.

the 28-day compressive strength for the cube

Table 8. Measured modulus of elasticity (GPa). 


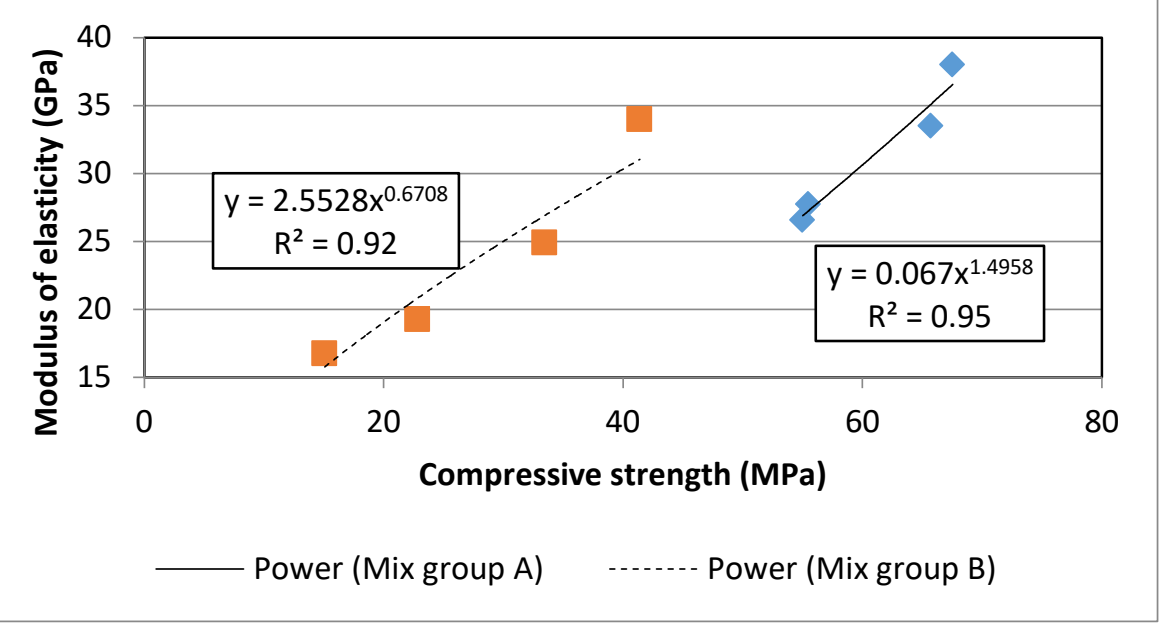

Fig.6. Compressive strength versus modulus of elasticity of mixes group A and B.

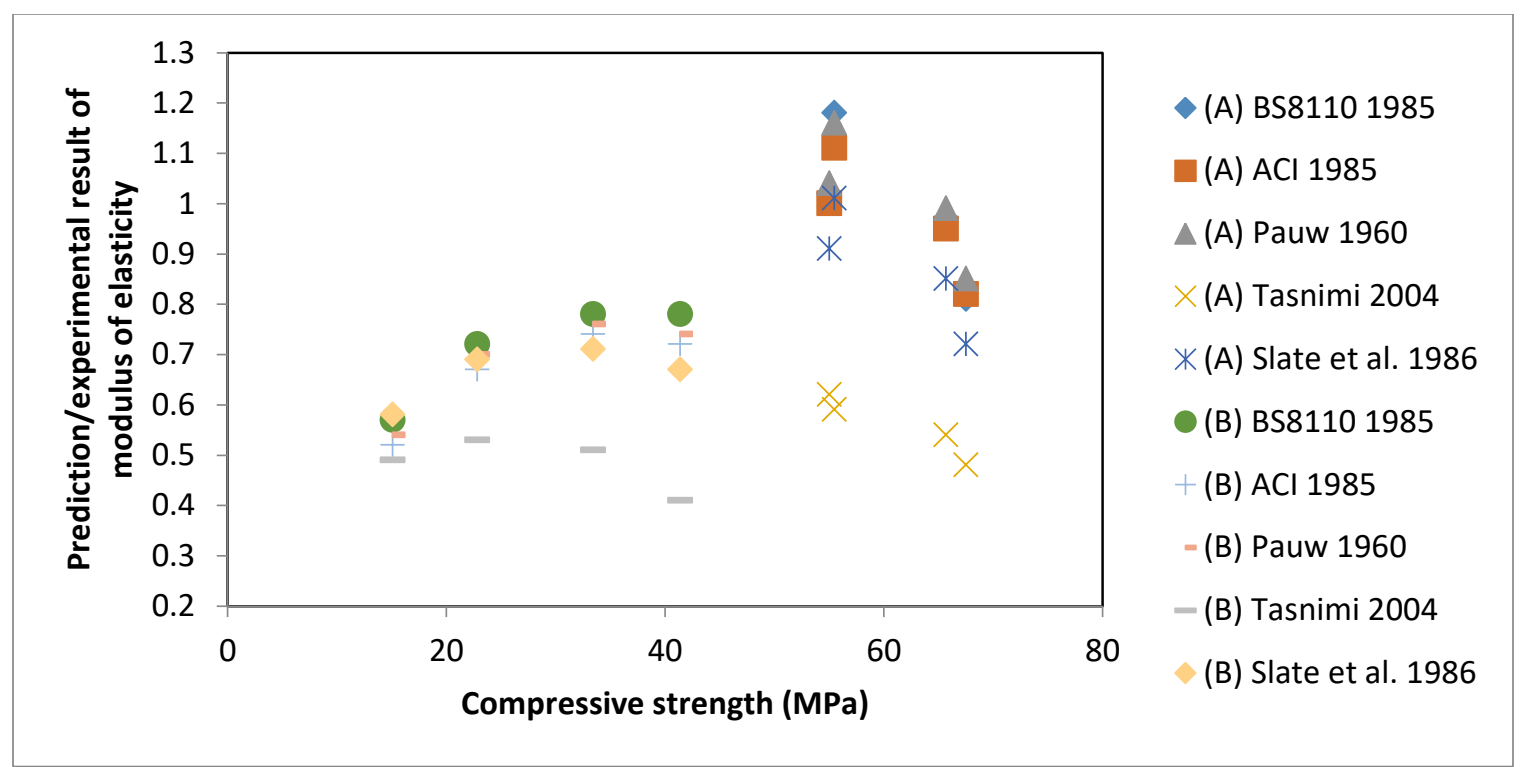

Fig. 7. Experimental and theoretical modulus of elasticity of mixtures

\subsection{Water Absorption}

The initial (30 minutes) water absorptions at the age of 28 days for all concrete mixes are shown in Figure 8. According to CEB-FIP (1989), categories for poor, average, and good for evaluation of the quality of concrete based on initial water absorption (water absorption in 30 minutes) are defined in the range of $5 \%$ and above, 3 to $5 \%$, and 0 to $3 \%$, respectively. Figure 8 shows that the initial absorptions of the three mixes are below $3 \%$, which can be assumed to have good quality of concrete. Moreover, the water absorption rates of OPBC-containing concrete (mix group A) and LECA-containing concrete (mix group B) were 9 to $64 \%$ and 39 to $136 \%$ higher than that of $\mathrm{CM}$, respectively. Highly porous OPBC aggregate has higher water absorption capacity than normal weight aggregate, as reported by Ahmad et al. (2007). However, the LECA containing concrete has the highest water absorption among all mixes because the LECA has the highest porosity. The inclusion of manufactured sand and slag in OPS concrete showed the initial water absorption within the range of 2.7 to $3.4 \%$ (Mo et al. 2016). 


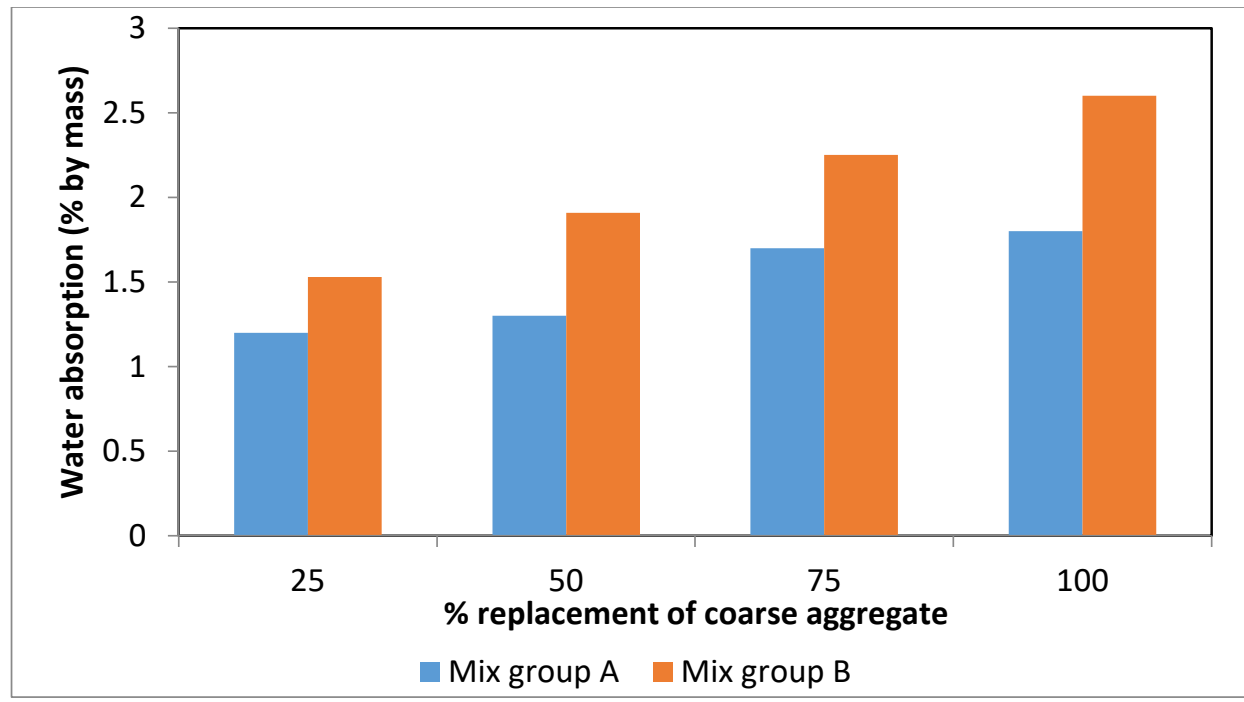

Fig. 8. Relationship between mix of concrete and water absorption.

\section{CONCLUSION}

A comparatively study has been proposed in this paper for the engineering properties of the Oilpalm-boiler clinker (OPBC) OPBC and lightweight expanded clay aggregate (LECA) concretes. According to the obtained results From the results obtained in this study, the following conclusions can be drawn:

1. The slump value decreases by increasing the OPBC and the LECA coarse aggregate in normal-weight concrete. Concrete containing the OPBC and the LECA exhibited acceptable workability.

2. Increasing the volume of OPBC and LECA in normal weight concrete leads to a reduction in density of the concrete. However, the oven-dry density of concrete containing 100\% OPBC (mix A100) and 50\% LECA onwards (mixes of B50, B75, and B100) in this study can be considered as lightweight concrete.

3. The 28-day compressive strength of OPBC concrete (mix group A) and LECA concrete (mix group B) is about 5 to $22 \%$ and 42 to $79 \%$ lower than that of normal weight concrete (mix $\mathrm{CM}$ ).

4. The ceiling strength of LECA concrete is at the early age of 7 days. However, it occurred at a later age for normal weight concrete and OPBC concrete.

5. The use of saturated OPBC and LECA in concrete improves the mechanical properties of concrete under $\mathrm{AC}$ condition. However, the saturated LECA was more sensitive to the lack of curing compared with crushed granite and $\mathrm{OPBC}$.

6. Two days of wet curing is almost the same or even higher for normal weight, OPBC-containing, and LECAcontaining concretes to reach the compressive strength of standard curing at the age of 28 days.

7. Inclusion of OPBC and LECA in normal weight concrete reduces the splitting tensile strength and flexural strength. However, the rate of reduction on the splitting tensile strength and flexural strength in LECA containing concrete is higher than that of OPBC containing concrete.

8. The MOE is strongly correlated with compressive strength for concrete containing OPBC and LECA at different ages. A close agreement with the measured data can predict the MOE values by using Eq. (1) for OPBCcontaining LWAC and Eq. (2) for LECA-containing LWAC.

9. The water absorption improves by increasing the substitution of OPBC and LECA. All mixes in this study can be considered as good concrete. 


\section{REFERENCES}

Abdullahi, M., Al-Mattarneh, H.M., Hasan, A.H. (2008). Trial mix design methodology for Palm Oil Clinker (POC) concrete. In The International Conference on Construction and Building Technology in Kuala Lumpur.

ACI Committee 318, (1995). Building code requirements for reinforced concrete (ACI 318-95). ACI, Farmington Hills, MI.

Ahmad, H., Hilton, M., Noor, N.M. (2007). Physical properties of local palm oil clinker and fly ash. Proceedings of EnCon2007. 1st Engineering conference on Energy and Environment, 27-28 Dec., Kuching, Sarawak.

Ahmad, M.H. and Noor, N.M. (2007). Physical properties of local palm oil clinker and fly ash. Proceedings of EnCon. 1st Engineering conference on Energy and Environment, 27-28 Dec. 2007, Kuching, Sarawak.

Ahmmad, R., Jumaat, M.Z., Bahri, S., Islam, A.B.M.S. (2014). Ductility performance of lightweight concrete element containing massive palm shell clinker. Construction and Building Materials, 63, 234-241.

ASTM C330-89 (2005). Standard Specification for Lightweight Aggregates for Structural Concrete. Annual Book of ASTM Standards.

Basri, H.B., Mannan, M.A., Zain, M.F.M. (1999). Concrete using waste oil palm shells as aggregate. Cement Concrete Res, 29, 619622.

Bentz, D.P., Jensen, O.M. (2004). Mitigation strategies for autogenous shrinkage cracking, Cem Concr Compos, 26, 677685.

Bentz, D.P., Lura, P., Roberts, J.W. (2005). Mixture proportioning for internal curing. ACI Concr Int, 27 (2), 35-40.

Bogas, J.A. and Gomes, A. (2013). Compressive behaviour and failure modes of structural lightweight aggregate concrete characterization and strength prediction. Materials and Design, 46, 832-841.

Bogas, J.A., Gomes, M.G., Real, S. (2014). Bonding of steel reinforcement in structural expanded clay lightweight aggregate concrete: The influence of failure mechanism and concrete composition. Construction and Building Materials, 65, 350-359.

BSI Document 92/17688. (1992). European Draft Standard Specification for lightweight aggregates, CEN/TC154/SC5, Sub Committee Lightweight Aggregates.

BS 8110: Part 2:1985. (1985). Structural use of concrete. Part 2: Code of practice for special circumstances. British Standards Institution, London.

Caldarone, M.A. (2009). High-strength concrete - a practical guide. Taylor \& Francis, Canada.

CEB-FIP. (1989). Diagnosis and assessment of concrete structures - "state of the art report'. CEB Bull, 192, 83-5.

CEB/FIP Manual of design and technology. (1977). Lightweight aggregate concrete. First pub, Great Britain.

Clarke, J.L., editor. (1993). Structural lightweight concrete. Blackie Academic \& Professional.

Cusson, D., Hoogeveen, T.J., Mitchell, L.D. (2005). Internally-cured high performance concrete under restrained shrinkage and creep. 7th International Symposium on utilization of High Strength/High Performance Concrete, Nates, France, 1214, p. 579-584.

Dhir, R.K., Hewlett, P.C., Lota, J.S., Dyre, T.D. (1994). An investigation into the feasibility of formulating self-curing concrete, Mater Struct, 27, 606-615.

Domagała, L. (2011). Modification of properties of structural lightweight concrete with steel fibres. J Civ Eng Manage, 17(1), 36-44.

Federico, L.M. and Chidiac, S.E. (2009). Waste glass as a supplementary cementitious material in concrete - critical review of treatment methods. Cement Concr Compos, 31, 606-10.

Fujji, K., Adachi, S., Takeuchi, M.T., Kakizaki, M., Edahiro, H., lnoue, T. (1998). Properties of high-strength and highfluidity lightweight concrete. ACI Spec Publ, 179, 65-84.

Haque, M.N. (1990). Some concretes need 7 days initial curing. ACI Con Int, 12(2), 426.

Hassan, A.H., Al-Mattarneh, H.M.A., Abdullahi, M. (2008). Compressive Strength and Absorption of Concrete Composed of Natural and Palm Oil Clinker (POC) Aggregates. ICCBT -A-(07), p. 93-100.

Holm, T.A. and Bremner, T.W. (2000). State of the art report on high strength, high durability structural low-density for applications in severe marine environments. US ARMY Corps of Engineers. 
Engineering Research and Development Center. ERDC/SL TR-00-3.

Jensen, O.M. and Hansen, P.F. (2001). Waterentrained cement-based materials I. Principle and theoretical background. Cem Concr Res, 31, 647-654.

Kanadasan, J. and Abdul Razak, H. (2015). Engineering and sustainability performance of self-compacting palm oil mill incinerated waste concrete. Journal of Cleaner Production, 89, 78-86.

Kockal, N.U. and Ozturan, T. (2011). Strength and elastic properties of structural lightweight concretes. Mater Des, 32, 2396-2403.

Kosmatka, S.H. and Wilson, M.L. (2011). Design and Control of Concrete Mixtures. EB001, fifteenth ed. Portland Cement Association, Skokie, Illinois, USA.

Lamond, J.F. and Pielert, J.H. (2006). Significance of tests and properties of concrete and concrete-making materials. PA: ASTM International Press2.

Lee, J.C., Shafigh, P., Mahmud, H.B., Aslam, H. (2017a). Effect of Substitution of Normal Weight Coarse Aggregate with Oil-PalmBoiler Clinker on Properties of Concrete. Sains Malaysiana. 46(4), 645-653.

Lee, J.C., Shafigh, P., Mahmud, H.B. (2017b). Production of high strength lightweight concrete using waste lightweight oil-palmboiler-clinker and limestone powder. European Journal of Environmental and Civil Engineering. 1-20.

Lo, T.Y., Tang, W.C., Nadeem, A. (2008). Comparison of carbonation of lightweight concrete with normal weight concrete at similar strength levels. Construction and Building Materials, 22, 1648-1655.

Mahmud, H., Shafigh, P., Jummaat, M.Z. (2013). Development of green high strength lightweight concrete in Malaysia. New Development in Structural Engineering and Construction, Yazdani, S. and Singh, A. (Eds.), ISEC-7, Honolulu, June 18-23.

Malhotra, V.M. (1990). Properties of highstrength, light-weight concrete incorporating fly ash and silica fume. ACI SP, 121-31.

Mannan, M.A. and Neglo, K. (2010). Mix design for oil-palm-boiler clinker (OPBC) concrete. Journal of Science and Technology, 30, 111-118.

Mather, B. (2001) Self-curing concrete, why not?. Concr Int 23, 46-47.
Mefteh, H., Kebaïli, O., Oucief, H., Berredjem, L., Nourredine Arabi, N. (2013). Influence of moisture conditioning of recycled aggregates on the properties of fresh and hardened concrete. J Clean Prod, 54, 282288.

Mehta, P.K. and Monteiro, P.J.M. (2006). Concrete: Microstructure, Properties and Materials, third ed. McGraw-Hill, USA, New York.

Meyer, C. (2009). The greening of the concrete industry. Cement and Concrete Composites, 31, 601-605.

Mo, K.H., Johnson, A.U., Jumaat, M.Z., Liu, M.Y.J., Lim, J. (2016). Assessing some durability properties of sustainable lightweight oil palm shell concrete incorporating slag and manufactured sand. Journal of Cleaner Production, 112, 763770.

Moreno, D., Zunino, F., Paul, A., Lopez, M. (2014). High strength lightweight concrete (HSLC): challenges when moving from laboratory to the field. Construction and Build Materials, 56, 44-52.

Mousa, M. I., Mahdy, M. G., Abdel-Raheem, A. H. and Yehia, A. Z. (2014). Mechanical properties of self-curing concrete (SCUC). Housing and Building National Research Centre Journal.

Mohammed, B.S., Foo, W.L., Abdullahi, M. (2014). Flexural strength of palm oil clinker concrete beams. Materials and Design, 53(16), 325-331.

Mohammed, B.S., Foo, W.L., Abdullahi, M. (2013). Shear strength of palm oil clinker concrete beams. Materials \& Design. 46, p. 270-276.

Netweber. (2015). Leca [Online]. Available from: <http://www.netweber.co.uk/fileadmin/user _upload/Literature/Leca__LWA_Brochur e_LR-V1.pdf> [Accessed 12 July 2015].

Novokshchenov, V. and Whitcomb, W. (1990). How to obtain high-strength concrete using low density aggregate. ACI SP, 121-23.

Okafor, F.O. (1988). Palm kernel shell as a lightweight aggregate for concrete. Cement Concrete Res, 18, 901-910.

Omar, W. and Mohamed, R.N. (2002). The performance of pre-tensioned concrete beams made with lightweight concrete. J Civ Eng, 14 (1), 60-70.

Pauw, A. (1960). Static Modulus of Elasticity of Concrete as Affected by Density. Journal Proceedings, concrete org, 57, 679-688. 
Priyadharshini, P., Ganesh, G.H., Santhi, A.S. (2012). A review on artificial aggregates. Int J Earth Sci Eng, 5(3), 540-6.

Ramezanianpour, A.A., Khani, M.M., Ahmadibeni, G.H. (2009). The effect of rice husk ash on mechanical properties and durability of sustainable concretes. International Journal of Civil Engineering, 7(2), 83-91.

Shafigh, P., Ghafari, H., Mahmud, H.B., Jumaat, M.Z. (2014). A comparison study of the mechanical properties and drying shrinkage of oil palm shell and expanded clay lightweight aggregate concretes. Materials and Design, 60, 320-327.

Shafigh, P., Lee, J.C., Mahmud H.B., Nomeli, M.A. (2018). A comparison study of the fresh and hardened properties of normal and lightweight concretes. Journal of Building Engineering. 15, 252-260.

Shafigh, P., Mahmud, H.B., Jumaat, M.Z. (2012a). Oil palm shell lightweight concrete as a ductile material. Materials and Design, 36, 650-654.

Shafigh, P., Jumaat, M.Z., Mahmud, H.B. (2012b). Effect of replacement of normal weight coarse aggregate with oil palm shell on properties of concrete. Arab J. Sci Eng, DOI 10.1007/s13369-012-0233-2.

Shetty, M.S. (2005). Concrete technology theory and practice. 3rd Multicolor illustrativesed, India.

Slate, F.O., Nilson, A.H., Martinez, S. (1986). Mechanical properties of high strength lightweight concrete. ACI J Proc, 83(7), 606-613.

Tasnimi, A.A. (2004). Mathematical model for complete stress-strain curve prediction of normal, light-weight and high-strength concretes. Mag Con Res, 56(1), 23-34.

Tu, T.Y., Chen, Y.Y., Hwang, C.L. (2006). Properties of HPC with recycled aggregates. Cement and Concrete Research, 36, 943950.

Wang, J., Dhir, R.K., Levitt, M. (1994). Membrane curing of concrete. Cem Concr Res, 24, 1463-1474.

Zheng, W., Kwan, A.K.H., Lee, P.K.K. (2001). Direct tension test of concrete. ACI Mater J, 98(1), 63-71. 